\title{
Demographical, Clinical, and Psychological Characteristics of Users and Nonusers of an Online Platform for T2DM Patients (e-VitaDM-3/ZODIAC-44)
}

\author{
Yvonne Roelofsen, ${ }^{1}$ Michael van Vugt, ${ }^{2}$ Steven H. Hendriks, ${ }^{1}$ \\ Kornelis J. J. van Hateren, ${ }^{1}$ Klaas H. Groenier, ${ }^{1,3}$ Frank J. Snoek, ${ }^{2}$ Nanne Kleefstra, ${ }^{1,4,5}$ \\ Robbert Huijsman, ${ }^{6}$ and Henk J. G. Bilo ${ }^{1,4}$ \\ ${ }^{1}$ Diabetes Centre, Isala, Zwolle, Netherlands \\ ${ }^{2}$ Department of Medical Psychology, VU University Medical Center and Academic Medical Center (AMC), Amsterdam, Netherlands \\ ${ }^{3}$ Department of General Practice, University of Groningen and University Medical Center Groningen, Groningen, Netherlands \\ ${ }^{4}$ Department of Internal Medicine, University of Groningen and University Medical Center Groningen, Groningen, Netherlands \\ ${ }^{5}$ Langerhans Medical Research Group, Zwolle, Netherlands \\ ${ }^{6}$ Institute of Healthcare Management \& Policy, Erasmus University Rotterdam, Rotterdam, Netherlands
}

Correspondence should be addressed to Yvonne Roelofsen; y.roelofsen@isala.nl

Received 7 January 2015; Accepted 30 April 2015

Academic Editor: Nitin Gupta

Copyright (C) 2016 Yvonne Roelofsen et al. This is an open access article distributed under the Creative Commons Attribution License, which permits unrestricted use, distribution, and reproduction in any medium, provided the original work is properly cited.

\begin{abstract}
Background. Online platforms offer opportunities for support in changing lifestyle and taking responsibility for one's health, but engaging patients with type 2 diabetes is challenging. Previous studies have shown that patients interested in platforms were more often male, younger, and higher educated. This study aims to investigate differences in clinical and psychological characteristics between users and nonusers of a newly developed platform. Methods. A prospective study started in the Drenthe region of Netherlands. Participants in the study concerning quality of care and quality of life were additionally invited to use the platform. Results. 633 patients were registered after they opted for platform use. Of these patients, 361 (57.0\%) never logged on, 184 (29.1\%) were labeled "curious" users, and 88 (13.9\%) were identified as "active" users. Users had lower HbAlc levels and more often hypertension compared to nonusers, and reported higher quality of life, better well-being, lower diabetes-related distress, and better medication adherence. Discussion. Platform use was associated with more favorable clinical and psychological characteristics relative to nonuse. Those with greater severity of disease, lower mood, and progression of disease used the platform the least. Other approaches need to be developed to reach these patients. Furthermore, improving the platform could also help to reach them. This trial is registered with Clinicaltrials.gov NCT01570140.
\end{abstract}

\section{Background}

Type 2 diabetes mellitus (T2DM) in itself is associated with poorer health-related quality of life (HRQoL) [1]. People with T2DM are susceptible to develop long term complications, such as retinopathy, neuropathy, nephropathy, and chronic heart disease, which negatively influence HRQoL [2]. To prevent or delay development of these long term complications, adequate treatment modalities are necessary which mainly involve lifestyle changes and pharmacological treatment.
Adherence to medication prescription and implementing life style changes are often better maintained and facilitated, when patients consider themselves more responsible for their treatment and have more knowledge regarding the causes and consequences of their disease. Improvements in knowledge about their disease can be described as promotion of health literacy. e-Health applications, such as web-portals, teleconsultation, and online care platforms, have the potential to support patients in changing lifestyle and taking more responsibility for their own health [3]. However, varying 


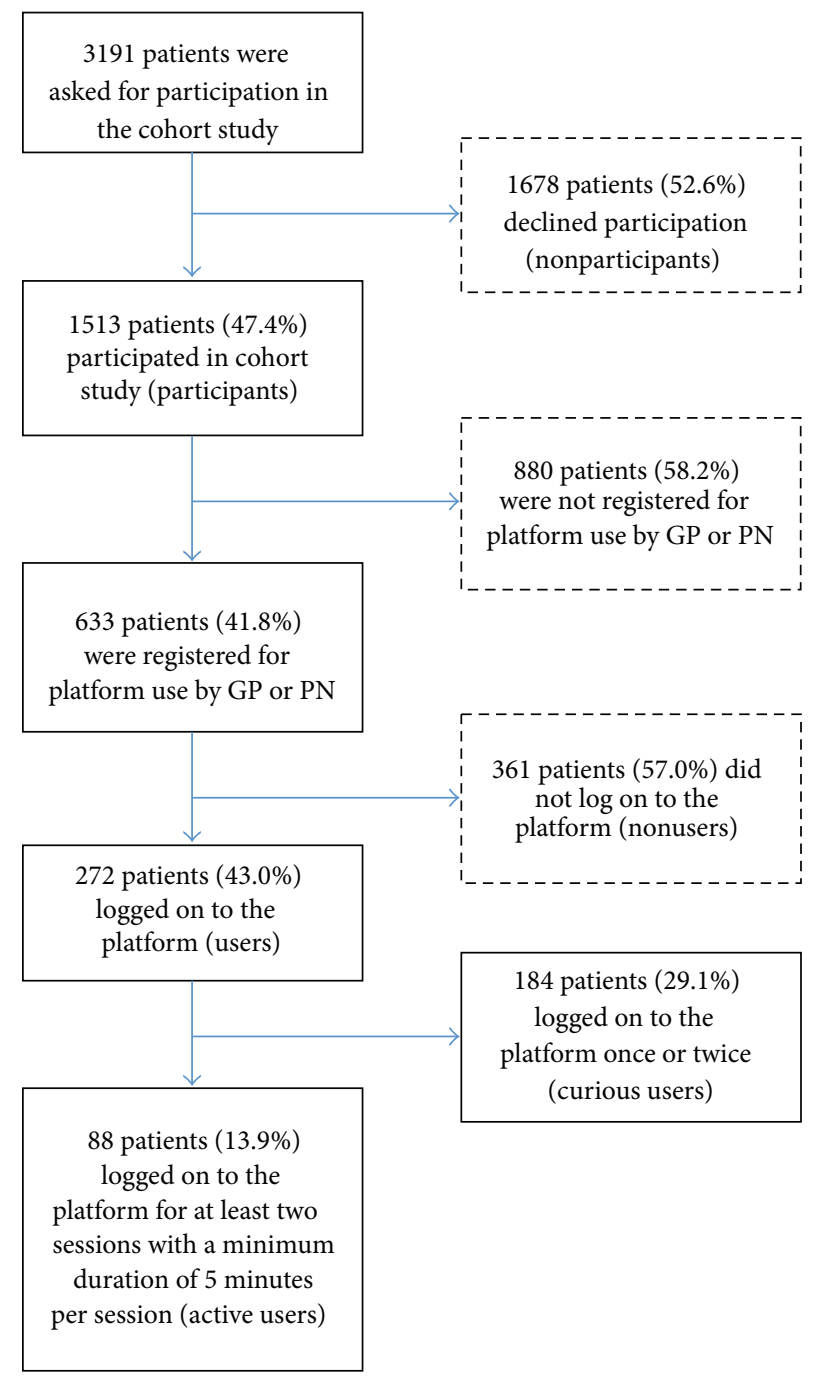

FIGURE 1: Flowchart of patients and definitions.

effects on clinical outcomes, quality of life, degree of self-care, perceived stress levels, patient satisfaction, and costs have been reported [4-10].

Previous studies showed that patients who were interested in using an online care platform were more often male, younger, and higher educated $[11,12]$. However, within the subgroup of interested patients these differences were not found between actual users and nonusers [11]. In addition, other factors associated with higher portal enrollment and utilization are higher income, nonblack race, higher selfefficacy, and having better regulated diabetes [13]. Identifying the differences between platform users and nonusers could provide information to help target and support nonusers in becoming more active in their diabetes self-management.

The aim of the present, explorative study was to investigate possible differences in demographic, clinical, and psychological characteristics between users and nonusers of the platform e-Vita.

\section{Methods}

2.1. Study Design. We performed a cross-sectional analysis of baseline data of users and nonusers of the online patient platform e-Vita. Data was obtained from a prospective observational cohort study. Detailed information about the methods and design of the study as a whole can be found elsewhere [14].

2.2. Study Population and Setting. Forty-three out of 110 general practices in the Drenthe region of the Netherlands invited their T2DM patients for participation in a prospective observational cohort study concerning quality of care and HRQoL. Patients were also invited to use the online care platform e-Vita, in addition to their usual treatment. Patients interested in using the platform were registered by their practice nurse $(\mathrm{PN})$ and received a user ID. In this ongoing study, participants were recruited from May 2012 onward. 

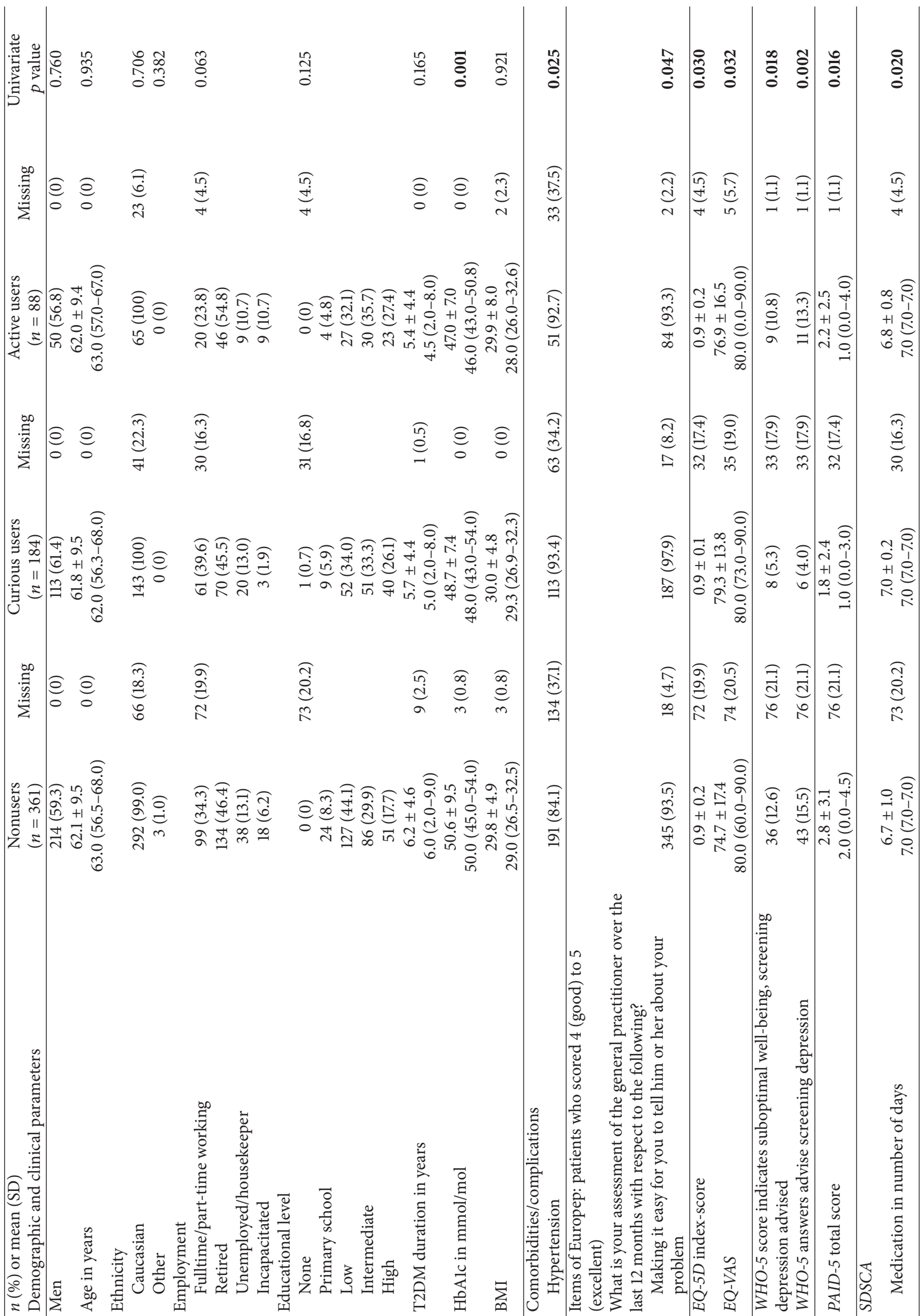
TABLE 2: Cronbach's alpha for multi-item scales.

\begin{tabular}{lr}
\hline Multi-item scale & $\alpha$ \\
\hline Europep & 0.963 \\
Total & 0.966 \\
Subscale general practice & 0.840 \\
Subscale general practitioner & 0.652 \\
EQ-5D & 0.872 \\
WHO-5 & 0.867 \\
PAID-5 & 0.517 \\
SDSCA & 0.875 \\
Total & 0.1 \\
Subscale general diet & $0.446^{2}$ \\
Subscale specific diet & 0.663 \\
Subscale total diet & 0.912 \\
Subscale exercise & 0.593 \\
Subscale blood-glucose testing & \\
Subscale foot-care & \\
\hline
\end{tabular}

${ }^{1}$ Because of the negative intercorrelation between the two items Cronbach's alpha is reported to be 0 .

${ }^{2}$ The alpha for the subscale total diet is lower than that for the subscale general diet due to the low reliability of the subscale specific diet.

The current analysis includes patients recruited from May 2012 till March 2014.

2.3. Measurements. Demographic and clinical data were obtained from the personal health record systems of the general practitioners (GP), based on a core dataset of T2DM related information as advised by the Dutch Diabetes Federation and the Dutch College of General Practitioners [14]. All T2DM patients participating in the study filled in a range of validated questionnaires concerning perceived quality of life measured by the EuroQol Five Dimension (EQ-5D) Scale [15-17], emotional well-being measured by the World Health Organization Wellbeing Index 5-Item (WHO-5) questionnaire $[18,19]$, diabetes-related distress measured by the Problem Areas in Diabetes 5-Item (PAID-5) questionnaire [20], diabetes self-care behavior measured by 7 Dimensions of the Summary of Diabetes Self-Care Activities (SDSCA) questionnaire [21], and quality of received care measured by the Europep [22]. Suboptimal emotional well-being was defined by a raw score lower than 13 on the WHO-5 [23]. Additional questions about smoking habits, employment, and educational background were also included. To identify users and nonusers, registration data from the application software and log-files were used.

2.4. Description of e-Vita Platform. The e-Vita platform for T2DM patients (accessible through the login button on https://www.e-vita.nl/) [11, 14, 24] contains the following components: (1) an overview of health data concerning annual check-ups from 2009 onward, (2) educational modules meant to support care through self-management by setting person-specific goals and actions [25], (3) prompting patient self-monitoring of clinical values, (4) educational modules aimed at increasing diabetes knowledge, and (5) providing reliable information on T2DM in general.
2.5. Users and Nonusers. Information about login status and log-data were used to group patients into nonusers and users. All patients who logged in at least once were considered as users. Patients who had been online for at least two sessions with a minimum of five minutes per session were defined as "active" users; other patients were defined as "curious" users. A session included all logins to the platform within thirty minutes [24].

2.6. Statistical Analyses. Statistical analyses were performed using SPSS version 20 (IBM Corporation, Somers, NY, USA). Quantitative variables are described in means and standard deviations when normally distributed; otherwise medians and interquartile ranges are also described. Categorical variables are described in numbers and percentages. To identify differences in the domains of interest between the different groups of users, the Linear Mixed Models procedure was used, with groups of users being fixed factors (nonusers being the reference group), while adjusting for age and sex. Fisher's exact test was used for categorical data. Differences were considered to be significant at a $p$ value of $<0.05$. In addition, results are adjusted for age and gender. Because of the explorative design of this study, no corrections for multiple testing were made [26]. Instead, the calculated $p$ values are only used as an indication of to what extent a difference could be interesting for further research.

2.7. Ethics. This study was approved by the Medical Ethical Review Committee of Isala, Zwolle, the Netherlands, and registered in Clinicaltrials.gov under number NCT01570140.

\section{Results}

In the period from May 2012 to March 2014, 3191 patients were invited to participate in the cohort study and to use the e-Vita 
TABLE 3: Results of multivariate analysis, adjusted for age and gender.

\begin{tabular}{|c|c|c|c|c|}
\hline & \multirow{2}{*}{$b$-coefficient } & \multicolumn{2}{|c|}{$95 \% \mathrm{CI}$} & \multirow{2}{*}{$p$ value } \\
\hline & & Lower bound & Upper bound & \\
\hline \multicolumn{5}{|c|}{ T2DM duration in years } \\
\hline Intercept & 0.018 & -2.325 & 2.360 & 0.988 \\
\hline Platform use & & & & 0.186 \\
\hline Active users & -0.845 & -1.876 & 0.186 & 0.108 \\
\hline Curious users & -0.511 & -1.300 & 0.277 & 0.203 \\
\hline Nonusers & Ref. Cat. & & & \\
\hline Male & -0.121 & -0.832 & 0.589 & 0.738 \\
\hline Female & Ref. Cat. & & & \\
\hline Age & 0.101 & 0.064 & 0.138 & $<0.0005$ \\
\hline \multicolumn{5}{|c|}{$\mathrm{HbAlc}$ in $\mathrm{mmol} / \mathrm{mol}$} \\
\hline Intercept & 53.431 & 48.931 & 57.931 & $<0.0005$ \\
\hline Platform use & & & & $<0.0005$ \\
\hline Active users & -3.624 & -5.627 & -1.621 & $<0.0005$ \\
\hline Curious users & -1.989 & -3.516 & -0.462 & 0.011 \\
\hline Nonusers & Ref. Cat. & & & \\
\hline Male & 1.103 & -0.270 & 2.477 & 0.115 \\
\hline Female & Ref. Cat. & & & \\
\hline Age & -0.055 & -0.127 & 0.016 & 0.126 \\
\hline \multicolumn{5}{|l|}{ BMI } \\
\hline Intercept & 37.430 & 34.658 & 40.202 & $<0.0005$ \\
\hline Platform use & & & & 0.924 \\
\hline Active users & 0.079 & -1.159 & 1.317 & 0.900 \\
\hline Curious users & 0.189 & -0.747 & 1.124 & 0.692 \\
\hline Nonusers & Ref. Cat. & & & \\
\hline Male & -1.087 & -1.931 & -0.244 & 0.012 \\
\hline Female & Ref. Cat. & & & \\
\hline Age & -0.113 & -0.156 & -0.069 & $<0.0005$ \\
\hline \multicolumn{5}{|l|}{ EQ-5D } \\
\hline Intercept & 0.866 & 0.773 & 0.958 & $<0.0005$ \\
\hline Platform use & & & & 0.022 \\
\hline Active users & 0.008 & -0.031 & 0.047 & 0.674 \\
\hline Curious users & 0.044 & 0.013 & 0.076 & 0.006 \\
\hline Nonusers & Ref. Cat. & & & \\
\hline Male & 0.056 & 0.027 & 0.085 & $<0.0005$ \\
\hline Female & Ref. Cat. & & & \\
\hline Age & -0.001 & -0.002 & 0.001 & 0.343 \\
\hline \multicolumn{5}{|l|}{ EQ-VAS } \\
\hline Intercept & 71.007 & 61.663 & 80.350 & $<0.0005$ \\
\hline Platform use & & & & 0.019 \\
\hline Active users & 2.291 & -1.691 & 6.275 & 0.259 \\
\hline Curious users & 4.611 & 1.384 & 7.838 & 0.005 \\
\hline Nonusers & Ref. Cat. & & & \\
\hline Male & 2.977 & 0.095 & 5.859 & 0.043 \\
\hline Female & Ref. Cat. & & & \\
\hline Age & 0.030 & -0.118 & 0.178 & 0.690 \\
\hline \multicolumn{5}{|l|}{ WHO-5 } \\
\hline Intercept & 58.138 & 48.911 & 67.365 & $<0.0005$ \\
\hline Platform use & & & & 0.065 \\
\hline Active users & -0.089 & -4.008 & 3.829 & 0.964 \\
\hline Curious users & 3.609 & 0.446 & 6.773 & 0.025 \\
\hline Nonusers & Ref. Cat. & & & \\
\hline Male & 5.766 & 2.932 & 8.600 & $<0.0005$ \\
\hline Female & Ref. Cat. & & & \\
\hline Age & 0.142 & -0.004 & 0.289 & 0.057 \\
\hline
\end{tabular}


TABLe 3: Continued.

\begin{tabular}{|c|c|c|c|c|}
\hline & \multirow{2}{*}{$b$-coefficient } & \multicolumn{2}{|c|}{$95 \% \mathrm{CI}$} & \multirow{2}{*}{$p$ value } \\
\hline & & Lower bound & Upper bound & \\
\hline \multicolumn{5}{|l|}{ PAID-5 } \\
\hline Intercept & 5.129 & 3.520 & 6.737 & $<0.0005$ \\
\hline Platform use & & & & 0.004 \\
\hline Active users & -0.511 & -1.195 & 0.173 & 0.143 \\
\hline Curious users & -0.929 & -1.480 & -0.378 & 0.001 \\
\hline Nonusers & Ref. Cat. & & & \\
\hline Male & -0.143 & -0.639 & 0.353 & 0.571 \\
\hline Female & Ref. Cat. & & & \\
\hline Age & -0.037 & -0.062 & -0.011 & 0.005 \\
\hline \multicolumn{5}{|c|}{ SDSCA-medication } \\
\hline Intercept & 6.087 & 5.575 & 6.600 & $<0.0005$ \\
\hline Platform use & & & & 0.028 \\
\hline Active users & 0.081 & -0.132 & 0.296 & 0.458 \\
\hline Curious users & 0.236 & 0.063 & 0.408 & 0.008 \\
\hline Nonusers & Ref. Cat. & & & \\
\hline Male & 0.096 & -0.058 & 0.250 & 0.222 \\
\hline Female & Ref. Cat. & & & \\
\hline Age & 0.010 & 0.002 & 0.018 & 0.020 \\
\hline
\end{tabular}

platform. 633 patients were registered for care platform use. See Figure 1 for the patient flow.

Table 1 shows all differences and other notable characteristics for the comparison between nonusers, curious users, and active users of the platform. No differences were found in demographical characteristics between nonusers, curious users, and active users. HbAlc level of nonusers was higher compared to curious users $(p=0.038)$ and to active users $(p=0.001)$. Curious and active users were more often known with hypertension compared to nonusers $(p=0.025)$. Curious users assessed the GP better on one question of the Europep compared to nonusers and active users $(p=0.047)$. Curious users scored higher on EQ-5D $(p=0.030)$ and EQVAS (0.032) compared to nonusers, with no significant differences between curious users and active users or nonusers and active users. In addition, curious users' WHO-5 score as well as their answers to the individual WHO-5 questions reported less depressive symptoms compared to nonusers and active users. Curious users scored lower on PAID-5 compared to nonusers $(p=0.016)$, with no significant differences between curious users versus active users and nonusers versus active users. Curious users performed better on one dimension of self-reported self-management activities (medication intake) compared to nonusers ( $p=0.020$ ), with no significant difference between curious users versus active users and nonusers versus active users. Table 2 shows the Cronbach's alpha for all the multi-item scales.

See Appendix A for tables with all characteristics as mentioned in the methods section for the comparison between nonusers and users. See Appendix B for tables with all characteristics for the comparison between nonusers, curious users, and active users.

The differences in characteristics between nonusers, curious users, and active users have also been adjusted for age and gender in a multivariate analysis. The results are shown in Table 3. $p$ values below 0.05 were found for differences regarding $\mathrm{HbAlc}$ between active users and nonusers $(-3.624 \mathrm{mmol} / \mathrm{mol})$ as well as between curious users and nonusers $(-1.989 \mathrm{mmol} / \mathrm{mol})$ and for differences between curious users and nonusers regarding EQ-5D (0.044), EQVAS (4.611), WHO-5 (3.609), PAID-5 (-0.929), and medication intake (0.236).

\section{Discussion}

In this exploratory study we found that only a small amount of clinical and psychological characteristics were associated with platform use. Curious users as well as active users had lower HbAlc compared to nonusers, which is in agreement with other studies $[27,28]$. The more frequent presence of hypertension in curious and active users, however, contradicts with these studies. Curious users scored higher on EQ5D and EQ-VAS and lower on PAID-5. Curious users scored also better on medication intake, which may reflect higher self-efficacy, in agreement with the study by Sarkar et al. [29]. After adjustment for age and gender, the difference in WHO-5 score between curious users and nonusers was also significant.

We observed that most of the patients, who were registered for platform use, never logged on. This could be 
TABLE 4: Demographic and clinical characteristics of users and nonusers.

\begin{tabular}{|c|c|c|c|c|c|}
\hline $\begin{array}{l}\text { Demographic and clinical } \\
\text { parameters } \\
n(\%) / \text { mean } \pm \mathrm{SD} / \text { median }(25-75 \\
\text { quartiles })\end{array}$ & $\begin{array}{l}\text { Nonusers } \\
(n=361)\end{array}$ & Missing & Users $(n=272)$ & Missing & $\begin{array}{c}\text { Univariate } \\
p \text { value }\end{array}$ \\
\hline Men & $214(59.3)$ & $0(0)$ & $163(59.9)$ & $0(0)$ & 0.95 \\
\hline Age in years & $\begin{array}{c}62.1 \pm 9.5 \\
63.0(56.5-68.0)\end{array}$ & $0(0)$ & $\begin{array}{c}61.8 \pm 9.4 \\
62.5(57.0-68.0)\end{array}$ & $0(0)$ & 0.732 \\
\hline \multicolumn{6}{|l|}{ Ethnicity } \\
\hline Caucasian & $292(99.0)$ & $66(18.3)$ & $208(100)$ & $64(2.5)$ & 0.271 \\
\hline Other & $3(1.0)$ & & $0(0)$ & & \\
\hline $\mathrm{T} 2 \mathrm{DM}$ duration in years & $\begin{array}{c}6.2 \pm 4.6 \\
6.0(2.0-9.0)\end{array}$ & $9(2.5)$ & $\begin{array}{c}5.6 \pm 4.4 \\
5.0(2.0-8.0)\end{array}$ & $1(0.4)$ & 0.068 \\
\hline $\mathrm{HbAlc}$ in $\mathrm{mmol} / \mathrm{mol}$ & $\begin{array}{c}50.6 \pm 9.5 \\
50.0(45.0-54.0)\end{array}$ & $3(0.8)$ & $\begin{array}{c}48.2 \pm 7.3 \\
47.0(43.0-53.0)\end{array}$ & $0(0)$ & $<0.0005$ \\
\hline BMI & $\begin{array}{c}29.8 \pm 4.9 \\
29.0(26.5-32.5)\end{array}$ & $3(0.8)$ & $\begin{array}{c}30.0 \pm 6.0 \\
28.7(26.3-32.4)\end{array}$ & $2(0.7)$ & 0.724 \\
\hline Systolic blood pressure in $\mathrm{mmHG}$ & $135.6 \pm 15.5$ & $0(0)$ & $136.5 \pm 16.0$ & $4(1.5)$ & 0.463 \\
\hline Cholesterol in mmol/L & $4.4 \pm 1.0$ & $4(1.1)$ & $4.4 \pm 0.9$ & $2(0.7)$ & 0.499 \\
\hline $\mathrm{HDL}$ in $\mathrm{mmol} / \mathrm{L}$ & $1.3 \pm 0.4$ & $4(1.1)$ & $1.3 \pm 0.4$ & $3(1.1)$ & 0.581 \\
\hline Cholesterol/HDL ratio & $3.6 \pm 1.1$ & $160(44.3)$ & $3.6 \pm 1.3$ & $92(33.8)$ & 0.899 \\
\hline $\mathrm{LDL}$ in $\mathrm{mmol} / \mathrm{L}$ & $2.4 \pm 0.9$ & $12(3.3)$ & $2.3 \pm 0.8$ & $6(2.2)$ & 0.240 \\
\hline Triglycerides in $\mathrm{mmol} / \mathrm{L}$ & $\begin{array}{c}1.7 \pm 1.0 \\
1.5(1.0-2.1)\end{array}$ & $7(1.9)$ & $\begin{array}{c}1.8 \pm 1.2 \\
1.5(1.1-2.1)\end{array}$ & $2(0.7)$ & 0.482 \\
\hline Creatinine in $\mu \mathrm{mol} / \mathrm{L}$ & $\begin{array}{c}78.6 \pm 17.2 \\
77.0(67.0-88.0)\end{array}$ & $6(1.7)$ & $\begin{array}{c}79.9 \pm 17.5 \\
79.0(67.0-90.0)\end{array}$ & $1(0.4)$ & 0.359 \\
\hline \multicolumn{6}{|l|}{ Alb./creat. ratio in $\mathrm{mg} / \mathrm{mmol}$} \\
\hline Men & $\begin{array}{c}2.0 \pm 4.4 \\
0.7(0.3-1.5)\end{array}$ & $23(10.7)$ & $\begin{array}{c}1.9 \pm 5.8 \\
0.5(0.3-1.5)\end{array}$ & $25(15.3)$ & 0.853 \\
\hline Women & $\begin{array}{c}1.6 \pm 3.5 \\
0.7(0.3-1.5)\end{array}$ & $31(21.1)$ & $\begin{array}{c}0.9 \pm 1.1 \\
0.6(0.4-1.2)\end{array}$ & $18(16.5)$ & 0.070 \\
\hline MDRD in $\mathrm{mL} / \mathrm{min} / 1.73 \mathrm{~m}^{2}$ & $\begin{array}{c}79.1 \pm 49.0 \\
75.0(61.0-88.0)\end{array}$ & $5(1.4)$ & $\begin{array}{c}76.0 \pm 16.6 \\
74.0(61.0-87.0)\end{array}$ & $1(0.4)$ & 0.329 \\
\hline \multicolumn{6}{|l|}{ Smoking } \\
\hline Yes & $54(15.1)$ & $3(0.8)$ & $41(15.1)$ & $1(0.4)$ & 0.306 \\
\hline Before & $158(44.1)$ & & $104(38.4)$ & & \\
\hline No & $146(40.8)$ & & $126(46.5)$ & & \\
\hline \multicolumn{6}{|l|}{ Alcohol consumption in units/day } \\
\hline 0 & $166(58.9)$ & $79(21.9)$ & $139(60.7)$ & $43(15.8)$ & 0.870 \\
\hline 1 & $61(21.6)$ & & $52(22.7)$ & & \\
\hline 2 & $39(13.8)$ & & $30(13.1)$ & & \\
\hline 3 & $11(3.9)$ & & $7(3.1)$ & & \\
\hline 4 & $4(1.4)$ & & $1(0.4)$ & & \\
\hline 5 & $0(0)$ & & $0(0)$ & & \\
\hline 6 & $1(0.4)$ & & $0(0)$ & & \\
\hline \multicolumn{6}{|l|}{ Employment } \\
\hline Fulltime/part-time working & $99(34.3)$ & $72(19.9)$ & $81(34.0)$ & $34(12.5)$ & 0.909 \\
\hline Retired & $134(46.4)$ & & $116(48.7)$ & & \\
\hline Unemployed/ housekeeper & $38(13.1)$ & & $29(12.2)$ & & \\
\hline Incapacitated & $18(6.2)$ & & $12(5.0)$ & & \\
\hline \multicolumn{6}{|l|}{ Educational level } \\
\hline None & $0(0)$ & $73(20.2)$ & $1(0.4)$ & $35(12.9)$ & 0.017 \\
\hline Primary school & $24(8.3)$ & & $13(5.5)$ & & \\
\hline Low & $127(44.1)$ & & $79(33.3)$ & & \\
\hline Intermediate & $86(29.9)$ & & $81(29.8)$ & & \\
\hline High & $51(17.7)$ & & $63(23.2)$ & & \\
\hline
\end{tabular}


TABLE 5: Medication use of users and nonusers.

\begin{tabular}{|c|c|c|c|c|c|}
\hline $\begin{array}{l}\text { Medication prescription } \\
n(\%)\end{array}$ & $\begin{array}{l}\text { Nonusers } \\
(n=361)\end{array}$ & Missing & $\begin{array}{c}\text { Users } \\
(n=272)\end{array}$ & Missing & $\begin{array}{l}\text { Univariate } \\
p \text { value }\end{array}$ \\
\hline \multicolumn{6}{|l|}{ Diabetes-related } \\
\hline Oral treatment only & $251(71.3)$ & $9(2.5)$ & $192(71.9)$ & $5(1.8)$ & 0.702 \\
\hline Insulin treatment only & $4(1.1)$ & $9(2.5)$ & $1(0.4)$ & $5(1.8)$ & 0.931 \\
\hline Mix of oral and insulin treatment & $40(11.4)$ & $9(2.5)$ & $23(8.6)$ & $5(1.8)$ & 0.248 \\
\hline No medication & $57(16.2)$ & $9(2.5)$ & $51(19.1)$ & $5(1.8)$ & 0.417 \\
\hline \multicolumn{6}{|l|}{ Comorbidity or complication related } \\
\hline Calcium channel blockers & $50(14.2)$ & $9(2.5)$ & $47(17.6)$ & $5(1.8)$ & 0.236 \\
\hline Beta blockers & $128(36.4)$ & $9(2.5)$ & $110(41.2)$ & $5(1.8)$ & 0.145 \\
\hline Diuretics & $121(34.4)$ & $9(2.5)$ & $94(35.2)$ & $5(1.8)$ & 0.870 \\
\hline Ace and RAAS inhibitors & $196(55.7)$ & $9(2.5)$ & $141(52.8)$ & $5(1.8)$ & 0.480 \\
\hline $\begin{array}{l}\text { Other blood pressure lowering } \\
\text { medications }\end{array}$ & $3(0.9)$ & $9(2.5)$ & $1(0.4)$ & $5(1.8)$ & 0.637 \\
\hline Lipid lowering medication & $280(79.5)$ & $9(2.5)$ & $213(79.8)$ & $5(1.8)$ & 0.847 \\
\hline
\end{tabular}

TABLE 6: Complications and risk factors of users and nonusers.

\begin{tabular}{|c|c|c|c|c|c|}
\hline $\begin{array}{l}\text { Complications and risk factors } \\
n(\%)\end{array}$ & $\begin{array}{l}\text { Nonusers } \\
(n=361)\end{array}$ & Missing & $\begin{array}{c}\text { Users } \\
(n=272)\end{array}$ & Missing & $\begin{array}{c}\text { Univariate } \\
p \text { value }\end{array}$ \\
\hline Cardiovascular, total & $225(96.2)$ & $127(35.2)$ & $187(98.4)$ & $82(30.1)$ & 0.240 \\
\hline \multicolumn{6}{|l|}{ Cardiovascular, specific } \\
\hline Angina pectoris & $41(21.7)$ & $172(47.6)$ & $28(19.7)$ & $130(47.8)$ & 0.787 \\
\hline Myocardial infarct & $29(15.3)$ & $172(47.6)$ & $23(16.0)$ & $128(47.1)$ & 0.880 \\
\hline Other/chronic ischemic heart diseases & $34(16.1)$ & $150(41.6)$ & $24(13.6)$ & $96(35.3)$ & 0.569 \\
\hline Hypertension & $191(84.1)$ & $134(37.1)$ & $164(93.2)$ & $96(35.3)$ & 0.008 \\
\hline TIA & $12(6.4)$ & $174(48.2)$ & $7(5.0)$ & $133(48.9)$ & 0.642 \\
\hline CVA & $13(7.0)$ & $176(48.8)$ & $10(7.1)$ & $132(48.5)$ & 1.000 \\
\hline Intermittent claudication & $7(3.3)$ & $150(41.6)$ & $7(4.0)$ & $96(35.3)$ & 0.788 \\
\hline Aortic aneurysms & $4(1.9)$ & $150(41.6)$ & $2(1.1)$ & $96(35.3)$ & 0.693 \\
\hline CABG & $15(5.1)$ & $68(18.8)$ & $11(5.4)$ & $68(25.0)$ & 1.000 \\
\hline PTCA & $28(9.6)$ & $68(18.8)$ & $14(6.8)$ & $67(24.6)$ & 0.327 \\
\hline Heart failure & $14(8.1)$ & $189(52.4)$ & $10(7.4)$ & $136(50.0)$ & 0.834 \\
\hline Retinopathy & $19(9.3)$ & $156(43.2)$ & $18(10.2)$ & $95(34.9)$ & 0.863 \\
\hline Renal impairment & $35(18.6)$ & $173(47.9)$ & $26(18.6)$ & $132(48.5)$ & 1.000 \\
\hline \multicolumn{6}{|l|}{ Albuminuria } \\
\hline Men & $30(14.5)$ & $7(3.3)$ & $20(12.6)$ & $4(2.5)$ & 0.647 \\
\hline Women & $8(5.8)$ & $8(5.4)$ & $1(1.0)$ & $5(4.6)$ & 0.082 \\
\hline Neuropathy & $49(22.2)$ & $140(38.8)$ & $39(22.4)$ & $98(36.0)$ & 1.000 \\
\hline \multicolumn{6}{|l|}{ Foot complication } \\
\hline SIMMs 0 & $228(77.6)$ & $67(18.6)$ & $161(76.7)$ & $62(22.8)$ & 0.783 \\
\hline SIMMs 1 & $57(19.4)$ & & $40(19.0)$ & & \\
\hline SIMMs 2 or 3 & $9(3.1)$ & & $9(4.3)$ & & \\
\hline Psychiatric disorders & $19(9.0)$ & $150(41.6)$ & $9(5.1)$ & $96(35.3)$ & 0.124 \\
\hline
\end{tabular}

SIMMS refers to risk factors in the diabetic foot, the number is the stage which ranges from $0-3$.

0 : no loss of protective sensibility (PS) \& Peripheral arterial disease (PAV).

1: loss of PS or PAV, with no signs of increased local pressure.

2: loss of PS in combination with and/or PAV and/or signs of local elevated pressure.

3: ulcer or amputation in history. 
TABLE 7: Scores on quality of care (Europep) of users and nonusers.

\begin{tabular}{|c|c|c|c|c|c|}
\hline $\begin{array}{l}\text { Items of Europep: patients who scored } 4 \text { (good) or } 5 \\
\text { (excellent) } \\
n(\%)\end{array}$ & $\begin{array}{l}\text { Nonusers } \\
(n=361)\end{array}$ & Missing & $\begin{array}{c}\text { Users } \\
(n=272)\end{array}$ & Missing & $\begin{array}{l}\text { Univariate } \\
p \text { value }\end{array}$ \\
\hline \multicolumn{6}{|l|}{$\begin{array}{l}\text { What is your assessment of the general practitioner over } \\
\text { the last } 12 \text { months with respect to the following? }\end{array}$} \\
\hline Making you feel you have time during consultation & $337(97.4)$ & $15(4.2)$ & $256(98.1)$ & $11(4.0)$ & 0.622 \\
\hline Showing interest in your personal situation & $324(94.5)$ & $18(5.0)$ & $246(94.6)$ & $12(4.4)$ & 0.864 \\
\hline $\begin{array}{l}\text { Making it easy for you to tell him or her about your } \\
\text { problem }\end{array}$ & $323(93.4)$ & $15(4.2)$ & $245(96.5)$ & $18(6.6)$ & 0.110 \\
\hline Involving you in decisions about your medical care & $311(92.3)$ & $24(6.6)$ & $239(94.1)$ & $18(6.6)$ & 0.290 \\
\hline Listening to you & $322(92.3)$ & $12(3.3)$ & $243(94.6)$ & $15(5.5)$ & 0.270 \\
\hline Keeping your records and data confidential & $310(95.7)$ & $37(10.2)$ & $236(95.9)$ & $26(9.6)$ & 0.846 \\
\hline Providing quick relief of your symptoms & $272(87.5)$ & $50(13.9)$ & $201(85.9)$ & $38(14.0)$ & 0.635 \\
\hline $\begin{array}{l}\text { Helping you to feel well so that you can perform your } \\
\text { normal daily activities }\end{array}$ & $265(89.8)$ & $66(18.3)$ & $196(91.2)$ & $57(21.0)$ & 0.483 \\
\hline Thoroughness of the approach to your problems & $308(91.4)$ & $24(6.6)$ & $227(89.7)$ & $19(7.0)$ & 0.786 \\
\hline Your physical examination & $292(90.1)$ & $37(10.2)$ & $222(92.1)$ & $31(11.4)$ & 0.327 \\
\hline $\begin{array}{l}\text { Offering services for preventing diseases (screening, } \\
\text { health checks, and immunizations) }\end{array}$ & $286(91.4)$ & $48(13.3)$ & $225(92.6)$ & $29(10.7)$ & 0.655 \\
\hline $\begin{array}{l}\text { Explaining the purpose of examinations, tests, and } \\
\text { treatments }\end{array}$ & $307(93.0)$ & $31(8.6)$ & $240(93.8)$ & $16(5.9)$ & 0.518 \\
\hline Telling you enough about your symptoms and/or illness & $306(92.2)$ & $29(8.0)$ & $238(93.3)$ & $17(6.3)$ & 0.448 \\
\hline $\begin{array}{l}\text { Helping you deal with emotions related to your health } \\
\text { status }\end{array}$ & $198(86.8)$ & $133(36.8)$ & $133(84.7)$ & $115(42.3)$ & 0.888 \\
\hline $\begin{array}{l}\text { Helping understand why it is important to follow the } \\
\text { GP's advice }\end{array}$ & $295(89.7)$ & $32(8.9)$ & $219(89.4)$ & $27(9.9)$ & 0.894 \\
\hline $\begin{array}{l}\text { Knowing what has been done or told during previous } \\
\text { contacts in the practice }\end{array}$ & $270(84.9)$ & $43(11.9)$ & $219(89.4)$ & $27(9.9)$ & 0.071 \\
\hline $\begin{array}{l}\text { Preparing you for what to expect from specialists, } \\
\text { hospital care, and other care providers }\end{array}$ & $199(85.4)$ & $128(35.5)$ & $156(83.5)$ & $85(31.3)$ & 0.513 \\
\hline \multicolumn{6}{|l|}{$\begin{array}{l}\text { What is your assessment of the general practice over the } \\
\text { last } 12 \text { months with respect to the following? }\end{array}$} \\
\hline $\begin{array}{l}\text { The helpfulness of the practice staff (other than the } \\
\text { doctor) to you }\end{array}$ & $313(93.4)$ & $26(7.2)$ & $235(92.9)$ & $19(7.0)$ & 0.878 \\
\hline Getting an appointment to suit you & $301(88.5)$ & $21(5.8)$ & $224(86.5)$ & $13(4.8)$ & 0.639 \\
\hline Getting through to the practice on telephone & $249(73.0)$ & $20(5.5)$ & $180(69.5)$ & $13(4.8)$ & 0.662 \\
\hline $\begin{array}{l}\text { Being able to talk to the general practitioner on the } \\
\text { telephone }\end{array}$ & $167(70.5)$ & $124(34.3)$ & $106(63.1)$ & $104(38.2)$ & 0.150 \\
\hline Waiting time in the waiting room & $246(71.3)$ & $16(4.4)$ & $170(65.4)$ & $12(4.4)$ & 0.175 \\
\hline Providing quick services for urgent health problems & $241(90.3)$ & $94(26.0)$ & $171(86.8)$ & $75(27.6)$ & 0.398 \\
\hline
\end{tabular}

influenced by (an insufficient) intrinsic motivation and (no) intention to change behaviours. Another explanation could be that patients do not see the platform as useful or as an added value to regular treatment. As an alternative explanation, login procedures might be too difficult and after trying for some time they might give up.
Previous research showed that web-portals and online care platforms are susceptible to implementation problems, low participation rates, and nonadherence, which, amongst others, can be caused by a mismatch in expectations between software developers, health care providers, and users [3037]. Other reasons for limited use of care platforms or 
TABLE 8: Scores on quality of life (EQ-5D), well-being (WHO-5), diabetes-related distress (PAID-5), and self-care behavior (SDSCA).

\begin{tabular}{|c|c|c|c|c|c|}
\hline $\begin{array}{l}\text { EQ-5D, WHO-5, PAID-5, and SDSCA } \\
n(\%) / \text { mean } \pm \text { SD/median ( } 25-75 \text { quartiles })\end{array}$ & $\begin{array}{l}\text { Nonusers } \\
(n=361)\end{array}$ & Missing & $\begin{array}{c}\text { Users } \\
(n=272)\end{array}$ & Missing & $\begin{array}{c}\text { Univariate } \\
p \text { value }\end{array}$ \\
\hline EQ-5D index-score & $0.9 \pm 0.2$ & $72(19.9)$ & $0.9 \pm 0.1$ & $36(13.2)$ & 0.028 \\
\hline EQ-VAS & $\begin{array}{c}74.7 \pm 17.4 \\
80.0(60.0-90.0)\end{array}$ & $74(20.5)$ & $\begin{array}{c}78.4 \pm 14.9 \\
80.0(71.0-90.0)\end{array}$ & $40(14.7)$ & 0.014 \\
\hline WHO-5 index-score & $\begin{array}{c}70.4 \pm 17.9 \\
76.0(60.0-80.0)\end{array}$ & $76(21.1)$ & $\begin{array}{c}72.7 \pm 14.2 \\
76.0(68.0-80.0)\end{array}$ & $38(14.0)$ & 0.096 \\
\hline $\begin{array}{l}\text { WHO- } 5 \text { score indicates suboptimal well-being, } \\
\text { screening depression advised }\end{array}$ & $36(12.6)$ & $76(21.1)$ & $17(7.3)$ & $38(14.0)$ & 0.018 \\
\hline WHO-5 answers advise screening depression & $43(15.5)$ & $76(21.1)$ & $17(7.3)$ & $38(14.0)$ & 0.004 \\
\hline PAID-5 total score & $\begin{array}{c}2.8 \pm 3.1 \\
2.0(0.0-4.5)\end{array}$ & $76(21.1)$ & $\begin{array}{c}2.0 \pm 2.5 \\
1.0(0.0-3.0)\end{array}$ & $38(14.0)$ & 0.005 \\
\hline PAID-5 score indicates distress & $15(5.3)$ & $76(21.1)$ & $6(2.6)$ & $38(14.0)$ & 0.058 \\
\hline \multicolumn{6}{|l|}{ SDSCA } \\
\hline General diet in number of days & $\begin{array}{c}5.4 \pm 1.8 \\
6.0(5.0-7.0)\end{array}$ & $76(21.1)$ & $\begin{array}{c}5.6 \pm 1.8 \\
6.0(5.0-7.0)\end{array}$ & $37(13.6)$ & 0.269 \\
\hline Specific diet in number of days & $\begin{array}{c}5.6 \pm 1.1 \\
5.7(4.7-6.3)\end{array}$ & $73(20.2)$ & $\begin{array}{c}5.7 \pm 1.0 \\
6.0(5.3-6.7)\end{array}$ & $34(12.5)$ & 0.056 \\
\hline Exercise in number of days & $\begin{array}{c}4.0 \pm 2.0 \\
4.0(2.5-5.5)\end{array}$ & $72(19.9)$ & $\begin{array}{c}4.0 \pm 1.8 \\
4.0(2.5-5.5)\end{array}$ & $34(12.5)$ & 0.919 \\
\hline Blood-glucose in number of days & $\begin{array}{c}2.1 \pm 2.2 \\
1.0(0.0-4.0)\end{array}$ & $74(20.5)$ & $\begin{array}{c}2.0 \pm 2.2 \\
1.0(0.5-3.5)\end{array}$ & $34(12.5)$ & 0.675 \\
\hline Foot-care in number of days & $\begin{array}{c}1.9 \pm 2.0 \\
1.5(0.0-3.5)\end{array}$ & $72(19.9)$ & $\begin{array}{c}1.9 \pm 2.0 \\
1.0(0.0-3.5)\end{array}$ & $34(12.5)$ & 0.695 \\
\hline Medication in number of days & $\begin{array}{c}6.7 \pm 1.0 \\
7.0(7.0-7.0)\end{array}$ & $73(20.2)$ & $\begin{array}{c}6.9 \pm 0.5 \\
7.0(7.0-7.0)\end{array}$ & $34(12.5)$ & 0.013 \\
\hline Smoking & $54(25.1)$ & $146(40.4)$ & $38(22.8)$ & $105(38.6)$ & 0.418 \\
\hline
\end{tabular}

nonadherence rates are as follows: abundance of functionalities on a platform, no connection with the needs of patients, implementation by management only without active involvement of care providers, no embedding in the regular care process, no space for habituation, underestimation of the complexity of lifestyle changes in general [38], and barriers to easy access to a portal (e.g., complicated login procedures). Despite the use of focus groups for designing and testing, these reasons might also be applicable to the e-Vita platform and improvements could be made.

The current study has some limitations. A preselection of participants could in part have influenced results. Only patients who expressed their interest received a user-ID [14]; see also Figure 1. Relevant and significant differences might be more difficult to find.

Data were not complete for all patients, especially with regard to complications and risk factors (complete for 50$60 \%$; see Tables 6 and 11). This may have led to an underestimation of presence of complications and risk factors. In addition, not all patients were seen by their GP or PN for the regular yearly check-up in the year 2012, which contributed to missing values in clinical parameters. Some questions about the assessment of the general practice and the general practitioner were poorly answered in general. A reason for this could be social desirability; patients may not like to be negative about their GP and prefer not answering these questions.

Although the online care platform e-Vita was designed for being suitable for all T2DM patients, a general assumption is that those with greater severity of disease, lower mood, progression of the disease, and complications would probably benefit most from an online care platform. However, when assessing the presented results, these patients use the platform the least.

Possibly, the current users were already more in control of their life and health and could therefore be more open to other forms of support, including e-Health facilities. Challenges to reach other patients remain manifold. A patients' passive attitude may not be overcome by only providing e-facilities, since one's interest and the sense of disease burden are low or even absent in the majority of the T2DM population. Factors as knowledge, motivation, and intention could be considered in future research. 
TABLE 9: Demographic and clinical characteristics of curious users, active users, and nonusers.

\begin{tabular}{|c|c|c|c|c|c|c|c|}
\hline $\begin{array}{l}\text { Demographic and clinical } \\
\text { parameters } \\
n(\%) / \text { mean } \pm \mathrm{SD} / \text { median } \\
(25-75 \text { quartiles }) \\
\end{array}$ & $\begin{array}{l}\text { Nonusers } \\
(n=361)\end{array}$ & Missing & $\begin{array}{l}\text { Curious users } \\
\quad(n=184)\end{array}$ & Missing & $\begin{array}{l}\text { Active users } \\
\quad(n=88)\end{array}$ & Missing & $\begin{array}{c}\text { Univariate } \\
p \text { value }\end{array}$ \\
\hline Men & $\begin{array}{l}214(59.3) \\
62.1 \pm 9.5\end{array}$ & $0(0)$ & $\begin{array}{l}113(61.4) \\
61.8 \pm 9.5\end{array}$ & $0(0)$ & $50(56.8)$ & $0(0)$ & 0.760 \\
\hline Age in years & $\begin{array}{c}63.0 \\
(56.5-68.0)\end{array}$ & $0(0)$ & $\begin{array}{c}62.0 \\
(56.3-68.0)\end{array}$ & $0(0)$ & $\begin{array}{c}62.0 \pm 9.4 \\
63.0(57.0-67.0)\end{array}$ & $0(0)$ & 0.935 \\
\hline \multicolumn{8}{|l|}{ Ethnicity } \\
\hline $\begin{array}{l}\text { Caucasian } \\
\text { Other }\end{array}$ & $\begin{array}{l}292(99.0) \\
3(1.0)\end{array}$ & $66(18.3)$ & $\begin{array}{c}143(100) \\
0(0)\end{array}$ & $41(22.3)$ & $\begin{array}{c}65(100) \\
0(0)\end{array}$ & $23(6.1)$ & $\begin{array}{l}0.706 \\
0.382\end{array}$ \\
\hline $\mathrm{T} 2 \mathrm{DM}$ duration in years & $\begin{array}{c}6.2 \pm 4.6 \\
6.0(2.0-9.0) \\
50.6 \pm 9.5\end{array}$ & $9(2.5)$ & $\begin{array}{c}5.7 \pm 4.4 \\
5.0(2.0-8.0) \\
48.7 \pm 7.4\end{array}$ & $1(0.5)$ & $\begin{array}{c}5.4 \pm 4.4 \\
4.5(2.0-8.0) \\
47.0 \pm 7.0\end{array}$ & $0(0)$ & 0.165 \\
\hline $\mathrm{HbAlc}$ in $\mathrm{mmol} / \mathrm{mol}$ & $\begin{array}{c}50.0 \\
(45.0-54.0) \\
29.8 \pm 4.9\end{array}$ & $3(0.8)$ & $\begin{array}{c}48.0 \\
(43.0-54.0) \\
30.0 \pm 4.8\end{array}$ & $0(0)$ & $\begin{array}{c}46.0 \\
(43.0-50.8) \\
29.9 \pm 8.0\end{array}$ & $0(0)$ & 0.001 \\
\hline BMI & $\begin{array}{c}29.0 \\
(26.5-32.5)\end{array}$ & $3(0.8)$ & $\begin{array}{c}29.3 \\
(26.9-32.3)\end{array}$ & $0(0)$ & $\begin{array}{c}28.0 \\
(26.0-32.6)\end{array}$ & $2(2.3)$ & 0.921 \\
\hline $\begin{array}{l}\text { Systolic blood pressure in } \\
\mathrm{mmHG}\end{array}$ & $135.6 \pm 15.5$ & $0(0)$ & $137.2 \pm 16.3$ & $2(1.1)$ & $135.1 \pm 15.3$ & $2(2.3)$ & 0.463 \\
\hline Cholesterol in $\mathrm{mmol} / \mathrm{L}$ & $4.4 \pm 1.0$ & $4(1.1)$ & $4.4 \pm 0.8$ & $0(0)$ & $4.4 \pm 0.9$ & $2(2.3)$ & 0.775 \\
\hline $\mathrm{HDL}$ in $\mathrm{mmol} / \mathrm{L}$ & $1.3 \pm 0.4$ & $4(1.1)$ & $1.2 \pm 0.3$ & $1(0.5)$ & $1.3 \pm 0.4$ & $2(2.3)$ & 0.071 \\
\hline Cholesterol/HDL ratio & $3.6 \pm 1.1$ & $160(44.3)$ & $3.7 \pm 1.4$ & $57(31.0)$ & $3.4 \pm 1.0$ & $35(39.8)$ & 0.185 \\
\hline $\mathrm{LDL}$ in $\mathrm{mmol} / \mathrm{L}$ & $2.4 \pm 0.9$ & $12(3.3)$ & $2.4 \pm 0.8$ & $3(1.6)$ & $2.3 \pm 0.8$ & $3(3.4)$ & 0.473 \\
\hline Triglycerides in $\mathrm{mmol} / \mathrm{L}$ & $\begin{array}{l}1.7 \pm 1.0 \\
1.5(1.0-2.1) \\
78.6 \pm 17.2\end{array}$ & $7(1.9)$ & $\begin{array}{c}1.8 \pm 1.3 \\
1.5(1.1-2.1) \\
80.9 \pm 17.4\end{array}$ & $0(0)$ & $\begin{array}{c}1.7 \pm 1.0 \\
1.4(1.0-2.0) \\
77.8 \pm 17.8\end{array}$ & $2(2.3)$ & 0.531 \\
\hline Creatinine in $\mu \mathrm{mol} / \mathrm{L}$ & $\begin{array}{c}77.0 \\
(67.0-88.0)\end{array}$ & $6(1.7)$ & $\begin{array}{c}79.0 \\
(68.0-92.0)\end{array}$ & $1(0.5)$ & $\begin{array}{c}75.5 \\
(66.0-85.8)\end{array}$ & $0(0)$ & 0.259 \\
\hline \multicolumn{8}{|l|}{ Alb./creat. ratio in $\mathrm{mg} / \mathrm{mmol}$} \\
\hline Men & $\begin{array}{c}2.0 \pm 4.4 \\
0.7(0.3-1.5)\end{array}$ & $23(10.7)$ & $\begin{array}{c}2.2 \pm 6.9 \\
0.5(0.3-1.5)\end{array}$ & $18(15.9)$ & $\begin{array}{c}1.3 \pm 1.7 \\
0.7(0.3-1.5)\end{array}$ & $7(14.0)$ & 0.636 \\
\hline Women & $\begin{array}{c}1.6 \pm 3.5 \\
0.7(0.3-1.5) \\
79.1 \pm 49.0\end{array}$ & $31(21.1)$ & $\begin{array}{c}1.1 \pm 1.3 \\
0.7(0.4-1.5) \\
757+162\end{array}$ & $8(11.3)$ & $\begin{array}{c}0.6 \pm 0.5 \\
0.6(0.3-0.9) \\
76.7 \pm 17.4\end{array}$ & $10(26.4)$ & 0.155 \\
\hline $\mathrm{MDRD}$ in $\mathrm{mL} / \mathrm{min} / 1.73 \mathrm{~m}^{2}$ & $\begin{array}{c}75.0 \\
(61.0-88.0)\end{array}$ & $5(1.4)$ & $\begin{array}{c}75.7 \pm 16.2 \\
73.0(61.0-87.0)\end{array}$ & $1(0.5)$ & $\begin{array}{c}75.5 \\
(61.0-89.0)\end{array}$ & $0(0)$ & 0.610 \\
\hline \multicolumn{8}{|l|}{ Smoking } \\
\hline Yes & $54(15.1)$ & $3(0.8)$ & $30(16.4)$ & $1(0.5)$ & $11(12.5)$ & $0(0)$ & 0.382 \\
\hline Before & $158(44.1)$ & & $73(39.7)$ & & $31(35.2)$ & & \\
\hline No & $146(40.8)$ & & $80(43.7)$ & & $46(52.3)$ & & \\
\hline \multicolumn{8}{|l|}{$\begin{array}{l}\text { Alcohol consumption in } \\
\text { units/day }\end{array}$} \\
\hline 0 & $166(58.9)$ & $79(21.9)$ & $98(60.9)$ & $23(12.5)$ & $41(60.3)$ & $20(22.7)$ & 0.646 \\
\hline 1 & $61(21.6)$ & & $8(23.6)$ & & $14(20.6)$ & & \\
\hline 2 & 39 (13.8) & & $17(10.6)$ & & $13(19.1)$ & & \\
\hline 3 & $11(3.9)$ & & $7(4.3)$ & & $0(0)$ & & \\
\hline 4 & $4(1.4)$ & & $1(0.5)$ & & $0(0)$ & & \\
\hline 5 & $0(0)$ & & $0(0)$ & & $0(0)$ & & \\
\hline 6 & $1(0.4)$ & & $0(0)$ & & $0(0)$ & & \\
\hline \multicolumn{8}{|l|}{ Employment } \\
\hline $\begin{array}{l}\text { Fulltime/part-time } \\
\text { working }\end{array}$ & $99(34.3)$ & $72(19.9)$ & $61(39.6)$ & $30(16.3)$ & $20(23.8)$ & $4(4.5)$ & 0.063 \\
\hline Retired & $134(46.4)$ & & $70(45.5)$ & & $46(54.8)$ & & \\
\hline Unemployed/housekeeper & $38(13.1)$ & & $20(13.0)$ & & $9(10.7)$ & & \\
\hline Incapacitated & $18(6.2)$ & & $3(1.9)$ & & $9(10.7)$ & & \\
\hline \multicolumn{8}{|l|}{ Educational level } \\
\hline None & $0(0)$ & $73(20.2)$ & $1(0.7)$ & $31(16.8)$ & $0(0)$ & $4(4.5)$ & 0.125 \\
\hline Primary school & $24(8.3)$ & & $9(5.9)$ & & $4(4.8)$ & & \\
\hline Low & $127(44.1)$ & & $52(34.0)$ & & $27(32.1)$ & & \\
\hline Intermediate & $86(29.9)$ & & $51(33.3)$ & & $30(35.7)$ & & \\
\hline High & $51(17.7)$ & & $40(26.1)$ & & $23(27.4)$ & & \\
\hline
\end{tabular}


TABLE 10: Medication prescription of curious users, active users, and nonusers.

\begin{tabular}{|c|c|c|c|c|c|c|c|}
\hline $\begin{array}{l}\text { Medication prescription } \\
n(\%)\end{array}$ & $\begin{array}{l}\text { Nonusers } \\
(n=361)\end{array}$ & Missing & $\begin{array}{c}\text { Curious users } \\
\quad(n=184)\end{array}$ & Missing & $\begin{array}{c}\text { Active users } \\
\quad(n=88)\end{array}$ & Missing & $\begin{array}{c}\text { Univariate } \\
p \text { value }\end{array}$ \\
\hline \multicolumn{8}{|l|}{ Diabetes-related } \\
\hline Oral treatment only & $251(71.3)$ & $9(2.5)$ & $128(71.5)$ & $5(2.7)$ & $64(72.7)$ & $0(0)$ & 1.000 \\
\hline Insulin treatment only & $4(1.1)$ & $9(2.5)$ & $1(0.5)$ & $5(2.7)$ & $0(0)$ & $0(0)$ & 0.899 \\
\hline $\begin{array}{l}\text { Mix of oral and insulin } \\
\text { treatment }\end{array}$ & 40 (11.4) & $9(2.5)$ & $18(10.1)$ & $5(2.7)$ & $5(5.7)$ & $0(0)$ & 0.242 \\
\hline No medication & $57(16.2)$ & $9(2.5)$ & $32(17.9)$ & $5(2.7)$ & $19(21.6)$ & $0(0)$ & 0.521 \\
\hline \multicolumn{8}{|l|}{$\begin{array}{l}\text { Comorbidity or complication } \\
\text { related }\end{array}$} \\
\hline Calcium channel blockers & $50(14.2)$ & $9(2.5)$ & $31(17.3)$ & $5(2.7)$ & $16(18.2)$ & $0(0)$ & 0.415 \\
\hline Beta blockers & $128(36.4)$ & $9(2.5)$ & $74(41.3)$ & $5(2.7)$ & $36(40.9)$ & $0(0)$ & 0.324 \\
\hline Diuretics & $121(34.4)$ & $9(2.5)$ & $63(35.2)$ & $5(2.7)$ & $31(35.2)$ & $0(0)$ & 0.979 \\
\hline Ace and RAAS inhibitors & $196(55.7)$ & $9(2.5)$ & $94(52.5)$ & $5(2.7)$ & $47(53.4)$ & $0(0)$ & 0.738 \\
\hline $\begin{array}{l}\text { Other blood pressure lowering } \\
\text { medications }\end{array}$ & $3(0.9)$ & $9(2.5)$ & $0(0)$ & $5(2.7)$ & $1(1.1)$ & $0(0)$ & 0.357 \\
\hline Lipid lowering medication & $280(79.5)$ & $9(2.5)$ & $141(78.8)$ & $5(2.7)$ & $72(81.8)$ & $0(0)$ & 0.868 \\
\hline
\end{tabular}

TABLE 11: Complications and risk factors of curious users, active users, and nonusers.

\begin{tabular}{|c|c|c|c|c|c|c|c|}
\hline $\begin{array}{l}\text { Complications and risk } \\
\text { factors } \\
n(\%)\end{array}$ & $\begin{array}{l}\text { Nonusers } \\
(n=361)\end{array}$ & Missing & $\begin{array}{l}\text { Curious users } \\
\quad(n=184)\end{array}$ & Missing & $\begin{array}{c}\text { Active users } \\
\quad(n=88)\end{array}$ & Missing & $\begin{array}{c}\text { Univariate } \\
p \text { value }\end{array}$ \\
\hline Cardiovascular, total & $225(96.2)$ & $127(35.2)$ & $128(98.5)$ & $54(29.3)$ & $59(98.3)$ & $28(31.8)$ & 0.506 \\
\hline \multicolumn{8}{|l|}{ Cardiovascular, specific } \\
\hline Angina pectoris & $41(21.7)$ & $172(47.6)$ & $21(21.4)$ & $86(46.7)$ & $7(15.9)$ & $44(50.0)$ & 0.698 \\
\hline Myocardial infarct & $29(15.3)$ & $172(47.6)$ & $15(15.3)$ & $86(46.7)$ & $8(17.4)$ & $42(47.7)$ & 0.932 \\
\hline $\begin{array}{l}\text { Other/chronic ischemic } \\
\text { heart diseases }\end{array}$ & $34(16.1)$ & $150(41.6)$ & $18(14.9)$ & $63(34.2)$ & $6(10.9)$ & $33(37.5)$ & 0.750 \\
\hline Hypertension & $191(84.1)$ & $134(37.1)$ & $113(93.4)$ & $63(34.2)$ & $51(92.7)$ & $33(37.5)$ & 0.025 \\
\hline TIA & $12(6.4)$ & $174(48.2)$ & $4(4.2)$ & $88(47.8)$ & $3(7.0)$ & $45(51.1)$ & 0.747 \\
\hline CVA & $13(7.0)$ & $176(48.8)$ & $6(6.1)$ & $86(46.7)$ & $4(9.5)$ & $46(52.3)$ & 0.745 \\
\hline Intermittent claudication & $7(3.3)$ & $150(41.6)$ & $4(3.3)$ & $63(34.2)$ & $3(5.5)$ & $33(37.5)$ & 0.689 \\
\hline Aortic aneurysms & $4(1.9)$ & $150(41.6)$ & $1(0.8)$ & $63(34.2)$ & $1(1.8)$ & $33(37.5)$ & 0.731 \\
\hline CABG & $15(5.1)$ & $68(18.8)$ & $7(5.0)$ & $43(23.4)$ & $4(6.3)$ & $25(28.4)$ & 0.916 \\
\hline PTCA & $28(9.6)$ & $68(18.8)$ & $9(6.4)$ & $43(23.4)$ & $5(7.8)$ & $24(27.3)$ & 0.588 \\
\hline Heart failure & $14(8.1)$ & $189(52.4)$ & $9(9.4)$ & $88(47.8)$ & $1(2.5)$ & $48(54.5)$ & 0.409 \\
\hline Retinopathy & $19(9.3)$ & $156(43.2)$ & $14(11.7)$ & $64(34.8)$ & $4(7.0)$ & $31(35.2)$ & 0.640 \\
\hline Renal impairment & $35(18.6)$ & $173(47.9)$ & $15(15.5)$ & $87(47.3)$ & $11(25.6)$ & $45(51.1)$ & 0.350 \\
\hline \multicolumn{8}{|l|}{ Albuminuria } \\
\hline Men & $30(14.5)$ & $7(3.3)$ & $14(12.6)$ & $2(1.8)$ & $6(12.5)$ & $2(4.0)$ & 0.908 \\
\hline Women & $8(5.8)$ & $8(5.4)$ & $1(1.4)$ & $1(1.4)$ & $0(0)$ & $4(10.5)$ & 0.226 \\
\hline Neuropathy & $49(22.2)$ & $140(38.8)$ & $30(24.6)$ & $62(33.7)$ & $9(17.3)$ & $36(40.9)$ & 0.594 \\
\hline \multicolumn{8}{|l|}{ Foot complication } \\
\hline SIMMs 0 & $228(77.6)$ & $67(18.6)$ & $105(73.4)$ & $41(22.3)$ & $56(83.6)$ & $21(23.9)$ & 0.524 \\
\hline SIMMs 1 & $57(19.4)$ & & $31(21.7)$ & & $9(13.4)$ & & \\
\hline SIMMs 2 or 3 & $9(3.1)$ & & $7(4.9)$ & & $2(3.0)$ & & \\
\hline Psychiatric disorders & $19(9.0)$ & $150(41.6)$ & $7(5.8)$ & $63(34.2)$ & $2(3.6)$ & $33(37.5)$ & 0.317 \\
\hline
\end{tabular}




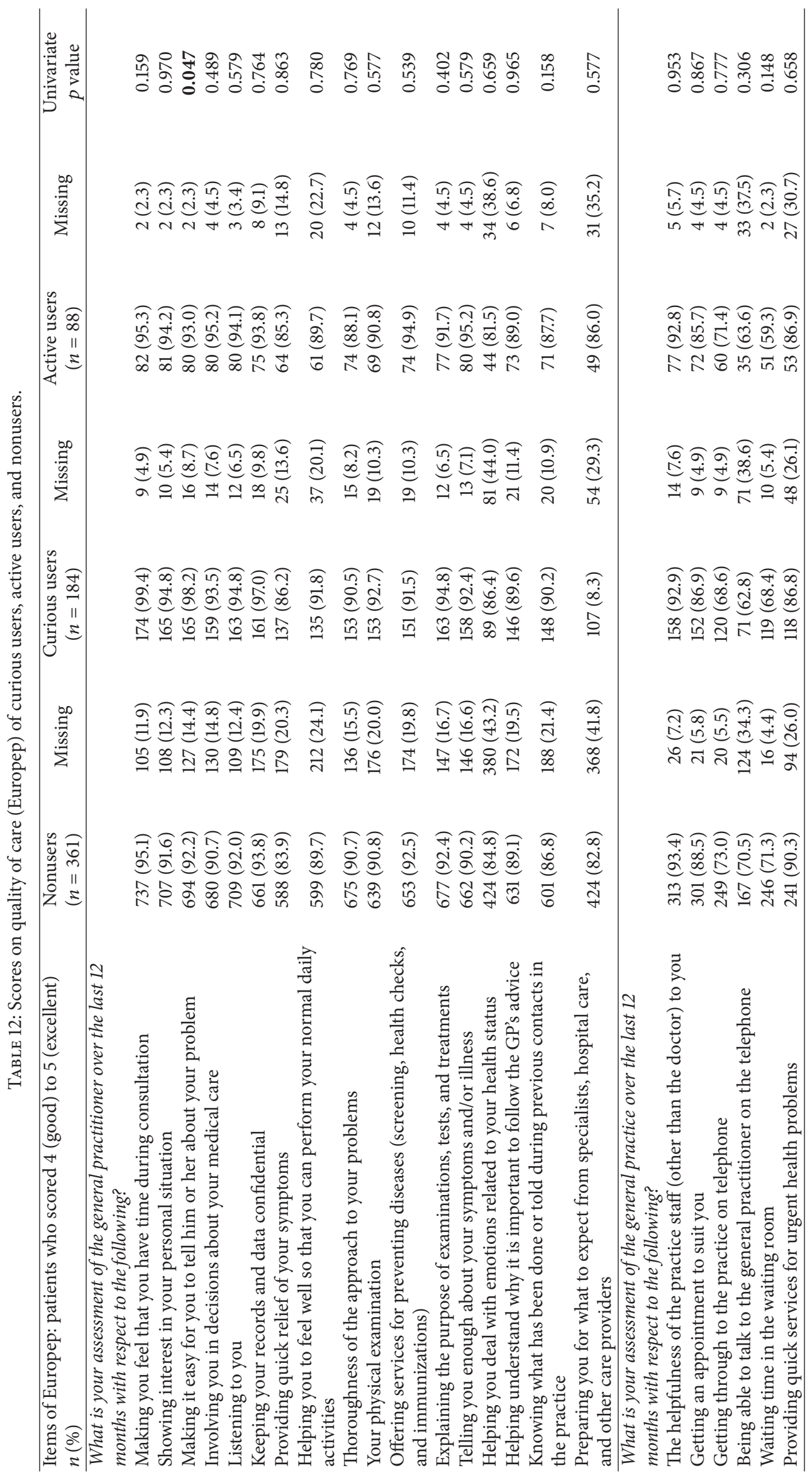


TABLE 13: Scores on quality of life (EQ-5D), well-being (WHO-5), diabetes-related distress (PAID-5), and self-care behavior (SDSCA) of curious users, active users, and nonusers.

\begin{tabular}{|c|c|c|c|c|c|c|c|}
\hline $\begin{array}{l}\text { EQ-5D, WHO-5, PAID-5, and } \\
\text { SDSCA } \\
n(\%) / \text { mean } \pm \text { SD/median }(25-75 \\
\text { quartiles) }\end{array}$ & $\begin{array}{l}\text { Nonusers } \\
(n=361)\end{array}$ & Missing & $\begin{array}{l}\text { Curious users } \\
\quad(n=184)\end{array}$ & Missing & $\begin{array}{l}\text { Active users } \\
\quad(n=88)\end{array}$ & Missing & $\begin{array}{c}\text { Univariate } \\
p \text { value }\end{array}$ \\
\hline EQ-5D index-score & $0.9 \pm 0.2$ & $72(19.9)$ & $0.9 \pm 0.1$ & $32(17.4)$ & $0.9 \pm 0.2$ & $4(4.5)$ & 0.030 \\
\hline EQ-VAS & $\begin{array}{c}74.7 \pm 17.4 \\
80.0 \\
(60.0-90.0)\end{array}$ & $74(20.5)$ & $\begin{array}{l}79.3 \pm 13.8 \\
80.0 \\
(73.0-90.0)\end{array}$ & $35(19.0)$ & $\begin{array}{c}76.9 \pm 16.5 \\
80.0(0.0-90.0)\end{array}$ & $5(5.7)$ & 0.032 \\
\hline WHO-5 index-score & $\begin{array}{c}70.4 \pm 17.9 \\
76.0 \\
(60.0-80.0)\end{array}$ & $76(21.1)$ & $\begin{array}{l}74.1 \pm 12.7 \\
76.0 \\
(68.0-80.0)\end{array}$ & $33(17.9)$ & $\begin{array}{l}70.2 \pm 16.5 \\
76.0 \\
(60.0-80.0)\end{array}$ & $1(1.1)$ & 0.080 \\
\hline $\begin{array}{l}\text { WHO- } 5 \text { score indicates } \\
\text { suboptimal well-being, screening } \\
\text { depression advised }\end{array}$ & $36(12.6)$ & $76(21.1)$ & $8(5.3)$ & $33(17.9)$ & $9(10.8)$ & $1(1.1)$ & 0.018 \\
\hline $\begin{array}{l}\text { WHO-5 answers advise } \\
\text { screening depression }\end{array}$ & $43(15.5)$ & $76(21.1)$ & $6(4.0)$ & $33(17.9)$ & $11(13.3)$ & $1(1.1)$ & 0.002 \\
\hline PAID-5 total score & $\begin{array}{c}2.8 \pm 3.1 \\
2.0(0.0-4.5)\end{array}$ & $76(21.1)$ & $\begin{array}{c}1.8 \pm 2.4 \\
1.0(0.0-3.0)\end{array}$ & $32(17.4)$ & $\begin{array}{c}2.2 \pm 2.5 \\
1.0(0.0-4.0)\end{array}$ & $1(1.1)$ & 0.016 \\
\hline PAID-5 score indicates distress & $15(5.3)$ & $76(21.1)$ & $4(2.6)$ & $32(17.4)$ & $2(2.4)$ & $1(1.1)$ & 0.183 \\
\hline \multicolumn{8}{|l|}{ SDSCA } \\
\hline General diet in number of days & $\begin{array}{c}5.4 \pm 1.8 \\
6.0(5.0-7.0)\end{array}$ & $76(21.1)$ & $\begin{array}{c}5.5 \pm 1.9 \\
6.0(5.0-7.0)\end{array}$ & $32(17.4)$ & $\begin{array}{c}5.8 \pm 1.7 \\
6.0(5.5-7.0)\end{array}$ & $5(5.7)$ & 0.258 \\
\hline Specific diet in number of days & $\begin{array}{c}5.6 \pm 1.1 \\
5.7(4.7-6.3)\end{array}$ & $73(20.2)$ & $\begin{array}{c}5.7 \pm 1.0 \\
6.0(5.0-6.7)\end{array}$ & $30(16.3)$ & $\begin{array}{c}5.7 \pm 1.0 \\
6.0(5.3-6.6)\end{array}$ & $4(4.5)$ & 0.160 \\
\hline Exercise in number of days & $\begin{array}{c}4.0 \pm 2.0 \\
4.0(2.5-5.5)\end{array}$ & $72(19.9)$ & $\begin{array}{c}4.1 \pm 1.8 \\
4.0(2.9-5.6)\end{array}$ & $30(16.3)$ & $\begin{array}{c}3.8 \pm 1.8 \\
3.8(2.5-5.0)\end{array}$ & $4(4.5)$ & 0.612 \\
\hline $\begin{array}{l}\text { Blood-glucose in number of } \\
\text { days }\end{array}$ & $\begin{array}{c}2.1 \pm 2.2 \\
1.0(0.0-4.0)\end{array}$ & $74(20.5)$ & $\begin{array}{c}2.1 \pm 2.4 \\
1.0(0.0-4.0)\end{array}$ & $30(16.3)$ & $\begin{array}{c}1.8 \pm 1.8 \\
1.0(0.5-2.3)\end{array}$ & $4(4.5)$ & 0.241 \\
\hline Foot-care in number of days & $\begin{array}{c}1.9 \pm 2.0 \\
1.5(0.0-3.5)\end{array}$ & $72(19.9)$ & $\begin{array}{c}1.9 \pm 2.0 \\
1.0(0.0-3.5)\end{array}$ & $30(16.3)$ & $\begin{array}{c}1.8 \pm 2.0 \\
1.0(0.0-3.5)\end{array}$ & $4(4.5)$ & 0.924 \\
\hline Medication in number of days & $\begin{array}{c}6.7 \pm 1.0 \\
7.0(7.0-7.0)\end{array}$ & $73(20.2)$ & $\begin{array}{c}7.0 \pm 0.2 \\
7.0(7.0-7.0)\end{array}$ & $30(16.3)$ & $\begin{array}{c}6.8 \pm 0.8 \\
7.0(7.0-7.0)\end{array}$ & $4(4.5)$ & 0.020 \\
\hline Smoking & $54(25.1)$ & $146(40.4)$ & $24(21.8)$ & $74(40.2)$ & $14(24.6)$ & $31(35.2)$ & 0.704 \\
\hline
\end{tabular}

\section{Appendices}

\section{A. Results of Users and Nonusers of the Online Care Platform e-Vita}

See Tables 4, 5, 6, 7, and 8 .

\section{B. Results of Curious Users, Active Users, and Nonusers of the Online Care Platform e-Vita}

See Tables 9, 10, 11, 12, and 13.

\section{Abbreviations}

EQ-5D: EuroQol-5 Dimensions EQ-VAS: EuroQol Visual Analogue Scale

GFR: Glomerular filtration rate

GP: $\quad$ General practitioner

HRQoL: Health-related quality of life
MDRD: Modification of Diet in Renal Disease

PAID-5: Problem Areas in Diabetes-5 questions PN: $\quad$ Practice nurse

SDSCA: Summary of Diabetes Self-Care Activities T2DM: Type 2 diabetes mellitus

WHO-5: WHO-Five Item Measure of Well-Being.

\section{Conflict of Interests}

The authors declare that there is no conflict of interests regarding the publication of this paper.

\section{Acknowledgments}

The authors wish to thank all the participating patients and primary health care workers in the Drenthe region of the Netherlands. Thanks also are due to Jurriaan Kok for his support and for managing the DM part of the eVita research program and all coordinators and supporters within the foundation Care Within Reach (in Dutch: stichting 
Zorg Binnen Bereik). The authors disclosed receipt of the following financial support for the research, authorship, and/or publication of this paper: the study has been funded by foundation Care Within Reach (in Dutch: stichting Zorg Binnen Bereik).

\section{References}

[1] R. R. Rubin and M. Peyrot, "Quality of life and diabetes," Diabetes/Metabolism Research and Reviews, vol. 15, no. 3, pp. 205-218, 1999.

[2] M. Poortvliet, C. T. M. Schrijvers, and C. A. Baan, Diabetes in Nederland. Omvang, Risicofactoren en Gevolgen, nu en in de Toekomst, 260322001, Rijksinstituut voor Volksgezondheid en Milieu (RIVM), Bilthoven, The Netherlands, 2007.

[3] P. C. Tang, J. S. Ash, D. W. Bates, J. M. Overhage, and D. Z. Sands, "Personal health records: definitions, benefits, and strategies for overcoming barriers to adoption," Journal of the American Medical Informatics Association, vol. 13, no. 2, pp. 121-126, 2006.

[4] F. Verhoeven, K. Tanja-Dijkstra, N. Nijland, G. Eysenbach, and L. Van Gemert-Pijnen, "Asynchronous and synchronous teleconsultation for diabetes care: a systematic literature review," Journal of Diabetes Science and Technology, vol. 4, no. 3, pp. 666$684,2010$.

[5] C. Y. Osborn, L. S. Mayberry, S. A. Mulvaney, and R. Hess, "Patient web portals to improve diabetes outcomes: a systematic review," Current Diabetes Reports, vol. 10, no. 6, pp. 422-435, 2010.

[6] A. D. Black, J. Car, C. Pagliari et al., "The impact of ehealth on the quality and safety of health care: a systematic overview," PLoS Medicine, vol. 8, no. 1, Article ID e1000387, 2011.

[7] P. S. Whitten, F. S. Mair, A. Haycox, C. R. May, T. L. Williams, and S. Hellmich, "Systematic review of cost effectiveness studies of telemedicine interventions," The British Medical Journal, vol. 324, no. 7351, pp. 1434-1437, 2002.

[8] M. Tenforde, A. Jain, and J. Hickner, "The value of personal health records for chronic disease management: what do we know?” Family Medicine, vol. 43, no. 5, pp. 351-354, 2011.

[9] H. Ko, T. Turner, C. Jones, and C. Hill, "Patient-held medical records for patients with chronic disease: a systematic review," Quality and Safety in Health Care, vol. 19, no. 5, p. e41, 2010.

[10] Y. Zhai, W. Zhu, Y. Cai, D. Sun, and J. Zhao, "Clinical- and cost-effectiveness of telemedicine in type 2 diabetes mellitus: a systematic review and meta-analysis," Medicine, vol. 93, no. 28, article e312, 2014.

[11] Y. Roelofsen, S. H. Hendriks, F. Sieverink et al., "Differences between patients with type 2 diabetes mellitus interested and uninterested in the use of a patient platform (e-VitaDM2/ZODIAC-41)," Journal of Diabetes Science and Technology, vol. 8, no. 2, pp. 230-237, 2014.

[12] M. C. M. Ronda, L.-T. Dijkhorst-Oei, K. J. Gorter, J. W. J. Beulens, and G. E. H. M. Rutten, "Differences between diabetes patients who are interested or not in the use of a patient web portal," Diabetes Technology and Therapeutics, vol. 15, no. 7, pp. 556-563, 2013.

[13] D. J. Amante, T. P. Hogan, S. L. Pagoto, and T. M. English, "A systematic review of electronic portal usage among patients with diabetes," Diabetes Technology \& Therapeutics, vol. 16, no. 11, pp. 784-793, 2014.

[14] Y. Roelofsen, S. H. Hendriks, F. Sieverink et al., "Design of the e-Vita diabetes mellitus study: effects and use of an interactive online care platform in patients with type 2 diabetes (e-VitaDM1/ZODIAC-40)," BMC Endocrine Disorders, vol. 14, no. 1, article 22, 2014.

[15] A. Williams, "EuroQol-a new facility for the measurement of health-related quality of life," Health Policy, vol. 16, no. 3, pp. 199-208, 1990.

[16] R. Brooks, "EuroQol: the current state of play," Health Policy, vol. 37, no. 1, pp. 53-72, 1996.

[17] L. M. Lamers, P. F. M. Stalmeier, J. McDonnell, P. F. M. Krabbe, and J. J. Van Busschbach, "Measuring the quality of life in costutility analyses: the Dutch EQ-5D tariff," Nederlands Tijdschrift voor Geneeskunde, vol. 149, no. 28, pp. 1574-1578, 2005.

[18] P. Bech, L. R. Olsen, M. Kjoller, and N. K. Rasmussen, "Measuring well-being rather than the absence of distress symptoms: a comparison of the SF-36 mental health subscale and the WHO-five well-being scale," International Journal of Methods in Psychiatric Research, vol. 12, no. 2, pp. 85-91, 2003.

[19] P. Bech, "Measuring the dimensions of psychological general well-being by the WHO-5," QOL Newsletter, vol. 32, pp. 15-16, 2004.

[20] B. E. McGuire, T. G. Morrison, N. Hermanns et al., "Short-form measures of diabetes-related emotional distress: the Problem Areas in Diabetes Scale (PAID)-5 and PAID-1," Diabetologia, vol. 53, no. 1, pp. 66-69, 2010.

[21] D. J. Toobert, S. E. Hampson, and R. E. Glasgow, "The summary of diabetes self-care activities measure: results from 7 studies and a revised scale," Diabetes Care, vol. 23, no. 7, pp. 943-950, 2000.

[22] R. Grol, M. Wensing, J. Mainz et al., "Patients in Europe evaluate general practice care: an international comparison," British Journal of General Practice, vol. 50, no. 460, pp. 882-887, 2000.

[23] WHO (Five) Well-Being Index (1998 Version), Psychiatric Research Unit, WHO Collaborating Center for Mental Health, Frederiksborg General Hospital, Hillerød, Denmark, 1998.

[24] F. Sieverink, S. M. Kelders, L. M. A. Braakman-Jansen, and J. E. W. C. van Gemert-Pijnen, "The added value of log file analyses of the use of a personal health record for patients with type 2 diabetes mellitus: preliminary results," Journal of Diabetes Science and Technology, vol. 8, no. 2, pp. 247-255, 2014.

[25] M. van Vugt, M. de Wit, S. H. Hendriks, Y. Roelofsen, H. J. G. Bilo, and F. J. Snoek, "Web-based self-management with and without coaching for type 2 diabetes patients in primary care: design of a randomized controlled trial," BMC Endocrine Disorders, vol. 13, article 53, 2013.

[26] R. Bender and S. Lange, "Adjusting for multiple testing-when and how?" Journal of Clinical Epidemiology, vol. 54, no. 4, pp. 343-349, 2001.

[27] U. Sarkar, A. J. Karter, J. Y. Liu et al., "Social disparities in internet patient portal use in diabetes: evidence that the digital divide extends beyond access," Journal of the American Medical Informatics Association, vol. 18, no. 3, pp. 318-321, 2011.

[28] M. Tenforde, A. Nowacki, A. Jain, and J. Hickner, "The association between personal health record use and diabetes quality measures," Journal of General Internal Medicine, vol. 27, no. 4, pp. 420-424, 2012.

[29] U. Sarkar, A. J. Karter, J. Y. Liu et al., "The literacy divide: health literacy and the use of an internet-based patient portal in an integrated health system-results from the diabetes study of Northern California (DISTANCE)," Journal of Health Communication, vol. 15, supplement 2, pp. 183-196, 2010. 
[30] D. H. Gustafson and J. C. Wyatt, "Evaluation of ehealth systems and services," British Medical Journal, vol. 328, no. 7449, article 1150, 2004.

[31] B. W. Hesse and B. Shneiderman, "eHealth research from the user's perspective," The American Journal of Preventive Medicine, vol. 32, supplement, no. 5, pp. S97-S103, 2007.

[32] S. J. Curry, "eHealth research and healthcare delivery beyond intervention effectiveness," The American Journal of Preventive Medicine, vol. 32, no. 5, supplement, pp. S127-S130, 2007.

[33] N. M. Hjelm, "Benefits and drawbacks of telemedicine," Journal of Telemedicine and Telecare, vol. 11, no. 2, pp. 60-70, 2005.

[34] D. Flynn, P. Gregory, H. Makki, and M. Gabbay, "Expectations and experiences of eHealth in primary care: a qualitative practice-based investigation," International Journal of Medical Informatics, vol. 78, no. 9, pp. 588-604, 2009.

[35] G. Eysenbach, "The law of attrition," Journal of Medical Internet Research, vol. 7, no. 1, article ell, 2005.

[36] S. C. Wangberg, T. S. Bergmo, and J.-A. K. Johnsen, "Adherence in internet-based interventions," Patient Preference and Adherence, vol. 2, pp. 57-65, 2008.

[37] N. Nijland, J. E. W. C. van Gemert-Pijnen, S. M. Kelders, B. J. Brandenburg, and E. R. Seydel, "Factors influencing the use of a web-based application for supporting the self-care of patients with type 2 diabetes: a longitudinal study," Journal of Medical Internet Research, vol. 13, no. 3, p. e71, 2011.

[38] D. Boshuizen, Patiëntenportaal Werkt niet Vanzelf, Medisch Contact, 2014. 


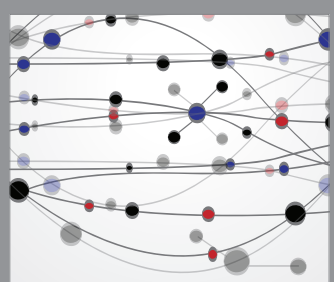

The Scientific World Journal
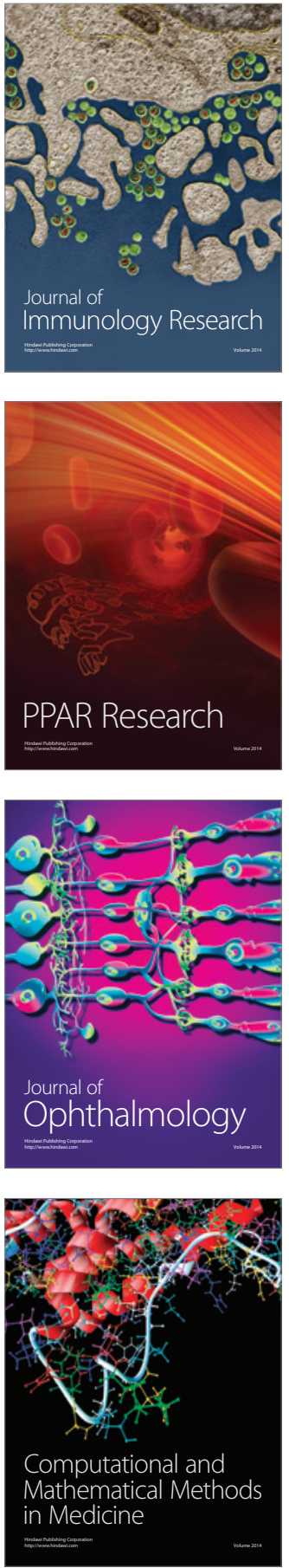

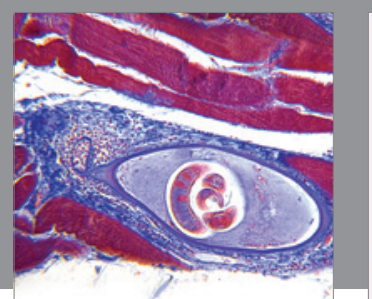

Gastroenterology Research and Practice

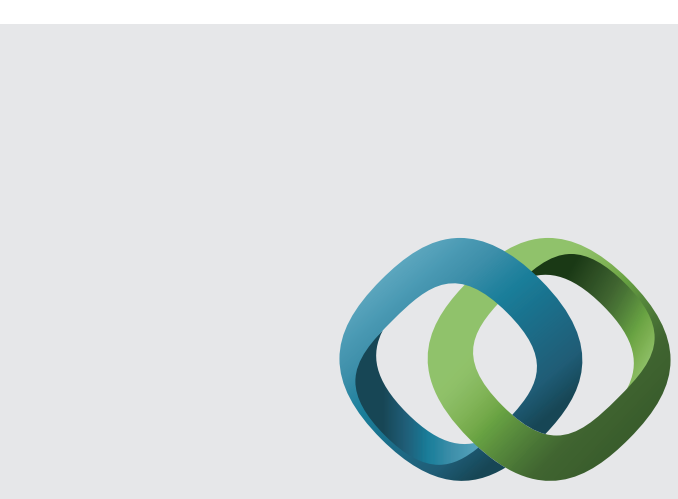

\section{Hindawi}

Submit your manuscripts at

http://www.hindawi.com
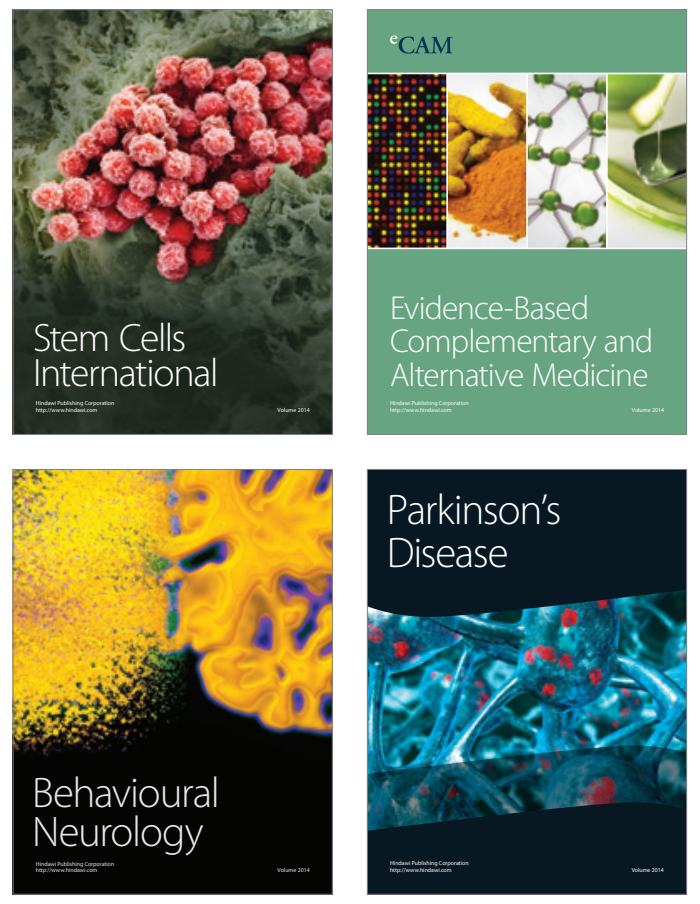
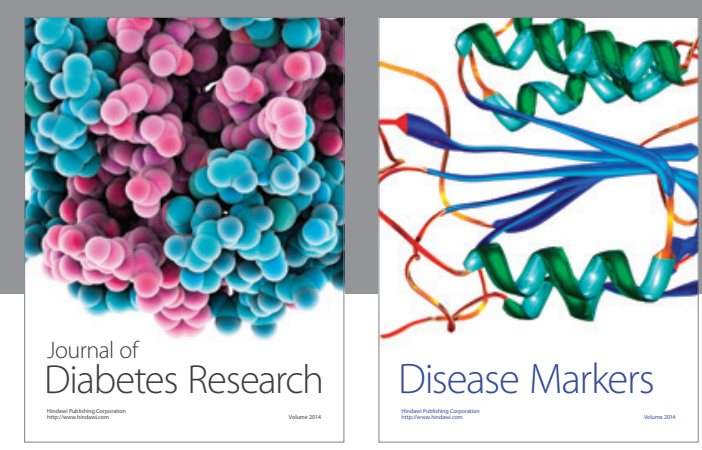

Disease Markers
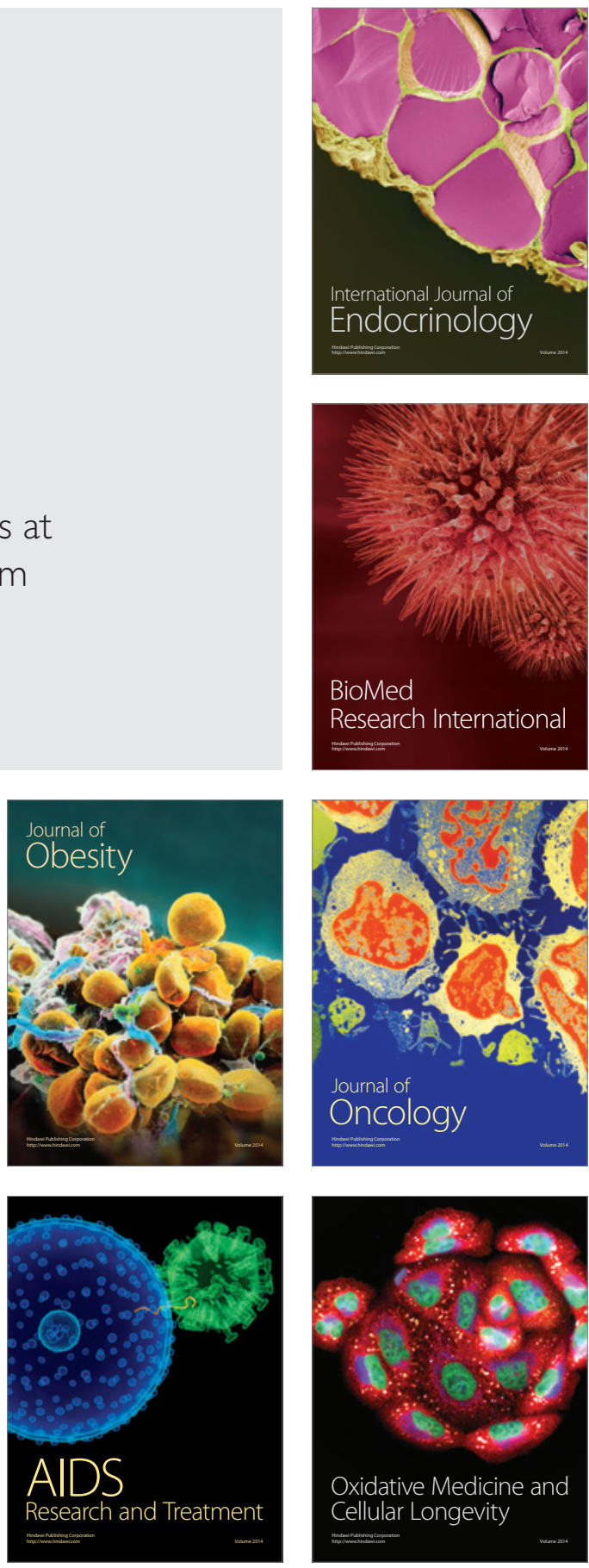